\title{
FUTURE TEACHERS RESOURCE-BASED LEARNING SYSTEM: EXPERIENCE OF HIGHER EDUCATION INSTITUTIONS IN POLTAVA CITY, UKRAINE
}

\author{
Dr. Natalia KONONETS \\ ORCID: 0000-0002-4384-1198 \\ Department of Enterprise Economics and \\ Economic Cybernetics of the University of Ukoopspilks \\ Poltava University of Economics and Trade \\ Poltava, UKRAINE
}

Dr. Olena ILCHENKO

ORCID: 0000-0003-4869-274X

Department of General Pedagogy and Andragogy

Poltava V. G. Korolenko National Pedagogical University

Poltava, UKRAINE

Dr. Volodymyr MOKLIAK

ORCID: 0000-0001-9922-7667

Department of General Pedagogy and Andragogy

Poltava V. G. Korolenko National Pedagogical University

Poltava, UKRAINE

Received: 05/08/2019 Accepted: 25/11/2019

\begin{abstract}
The article explores the problem of introducing resource-based learning (RBL) in higher education institutions as a holistic dynamic process of organizing and stimulating the independent cognitive activity of students for mastering the skills of the active transformation of the information environment, which involves the optimal use of the triad "student-teacher-librarian" of the consolidated personnel, logistical, methodological, financial and information resources. The effectiveness of the RBL system of future teachers, which consists of 5 subsystems (conceptual-target, structural-content, process-technological, motivational, diagnostic and productive) is theoretically substantiated and experimentally verified. The RBL system was implemented in the higher educational establishments of Poltava region. The organizational and pedagogical conditions of the implementation of the RBL system of future teachers as a set of interconnected circumstances, measures ensuring the purposeful management of the process of mixed learning, and the rules established in the system for ensuring high quality of professional training in higher educational establishments are identified. On the basis of pedagogical experiment was made the Implementation of future teachers in the RBL of higher educational establishments in Poltava region (Poltava V. G. Korolenko National Pedagogical University, University of Ukoopspilks "Poltava University of Economics and Trade"). Among the research methods used are: methods theoretical (analysis, comparison, generalization); methods pedagogical (pedagogical experiment, pedagogical observation); social and psychological methods (questioning), mathematical methods (mathematical calculation, ranking, regression). Poltava V. G. Korolenko National Pedagogical University, University of Ukoopspilks "Poltava University of Economics and Trade" were the basis of the empirical research. The undergraduates of the VI course of full-time and external forms of study of specialty "Secondary education", educational programs "Secondary education (natural sciences)", "Secondary education (computer science)", "Secondary education (mathematics)" (Poltava V. G. Korolenko National Pedagogical University) and undergraduate students of the 6th year of the stationary and correspondence form of study in the specialty "Educational, Pedagogical Sciences", educational program "Pedagogics of
\end{abstract}


Higher School" (University of Ukoopspilks "Poltava University of Economics and Trade") were made the sample of the study. The entire period of study in the magistracy -1.4 years was covered by the study. It was conducted in two stages: the first (2018) - at the beginning of the experiment, before the introduction of the RBL system; the second (2019) - at the end of the experiment, after the implementation of the RBL system. Quantitative indicators of the pedagogical experiment involved 253 persons in control group (CG) and 240 persons in experimental group (EG).

Keywords: Resource-based learning, blended learning, e-learning, distance course, electronic manual, open learning environment, virtual class, electronic library

\section{INTRODUCTION}

There are intensive searches for ways of developing education as the basis of intellectual, spiritual, cultural, social, economic development of society and the state in the context of global changes and restructuring of the world, and Ukraine in particular. Modern world educational standards put new demands on higher education in Ukraine: individualization of education, use of new information and communication technologies, pedagogical innovations, strengthening of organic unity of education and self-education, transformation of the teacher's role, new role of library and librarian, creation of preconditions for organization of lifelong learning - a task to be solved by providing high-quality education, constant professional improvement and competitiveness of university graduates of Ukraine.

Teachers of many countries around the world are concerned that the current content of education, methods of its acquisition are not productive and do not sufficiently satisfy the student's need for personal use of knowledge during their studies, after graduating, in their life and professional activity. Therefore, teachers pursue productive education, in which the product's extent becomes a student with his interests, experience and educational goals. These tasks can be solved using resource-based learning (RBL), which has been long implemented in educational systems of such countries as Australia, Austria, Great Britain, Ireland, Canada, China, Germany, Norway, Singapore, the USA, Taiwan, Sweden, Switzerland, Finland, etc.

Problems of resource-based learning (RBL) are thoroughly investigated by foreign scientists M. Butler, M. Hannafin, J. Hill, C. Greenhow, S. Dexter, B. Greene, S. Land, C. Laverty, H. Niemi, E. Riedel, S. Hadjerrouit, Shu-Nu Chang, I. Sikstrom, M.-A. Westerlund and others, which clearly emphasize the importance of RBL and see the prospect of expanding educational opportunities provided full-scale transition of educational establishments to RBL.

Scientists understand under RBL:

- e-learning on the basis of modern network technologies, which contributes to the development of the scientific potential of those who study (LeoTanWeeHin, Subramaniam, 2005, Greenhow, Dexter, Riedel, 2006);

- web-based learning, the potential of which is so large, how much is the World Wide Web's educational resources (Hadjerrouit, 2010);

- learning, that promotes the creation of information and educational environment of an educational institution with the involvement of resources of libraries, scientific centers, other education institutions of the region, the country, the world education community (Hannafin, Hill, 2008);

- organic interaction of contact learning (directly "teacher-student") and the virtual one (Niemi, 2008);

- information culture development strategy (Sikstrom, Westerlund, 2011);

- active interaction of students with several learning resources with clearly defined educational goals, which implies collaboration in groups (Laverty, 2001);

- learning educational material by finding information using a variety of resources (Chang, 2007);

- a pedagogical approach, based on a project-oriented learning, in which students work with a wide range of educational resources (Greene, Land, 2000, Butler, 2011). 
We agree with the above-mentioned scholars and define RBL in higher education institutions as a holistic dynamic process of organizing and stimulating the independent cognitive activity of students for mastering the skills of the active transformation of the information environment, which involves the optimal use of the triad "student-teacher-librarian" of the consolidated personnel, logistical, methodological, financial and information resources.

Under the transformation of the information environment is understood study, analytical and synthetic analysis of the content of information, regrouping and change its values and form, preparation of its new form (secondary information), convenient for future use. Note that when converting information it is expedient to use the following methods of analysis: composition, decomposition, classification, abstraction, generalization, analogy, synthesis, systematization, integration, comparison.

Based on the analysis of researches of scientists in the field of resource-oriented learning, it is found out that similar systems, the implementation mechanism of which is contact learning (directly "student-teacher" in classrooms) and virtual (distance courses, sites and other electronic resources), are implemented at training of managers, marketers, economists, lawyers, specialists in information technologies, agrarians, as it forms the ability of students to work effectively, make non-standard decisions independently, take a comprehensive approach to the evaluation results, the choice of ways of their activity (Kononets, 2016).

In general, such scholarships and practitioners are not given such attention to date, although some of its elements, such as distance learning, on-line learning, ICT applications, blended learning, are, of course, quite common. In the process of professional training of future teachers, RBL was not implemented, so we decided to develop a RBL system for future teachers and to implement it in higher education establishments.

Therefore, the task of our study is to develop, theoretically substantiate and experimentally test the effectiveness of the future teachers' RBL system; to distinguish organizational and pedagogical conditions for the implementation of the RBL system of future teachers.

\section{THEORETICAL FRAMEWORK}

Exploring the theoretical and practical aspect of RBL, our attention is drawn to the study of educators and scholars of the University of Greenwich, who introduced RBL in the course in economics. A number of activities have been implemented: delivery of educational materials (curriculum, teaching support, etc.) and assessment of students' knowledge in the disciplines using computer and information technology; open approach to evaluation; cancellation of lectures in favor of various forms and methods of teaching (Ryan, Wells, Freeman, Hallam, 1996). The introduction of the RBL at the College of Liberal and General Education, Aletheia University (Taiwan) was carried out among a community of part-time students working in business and management while "Logic course" studying. The main method of training was to identify the project method and the search for information related to each topic, basic concepts, questions and conclusions. Students prepared presentations and written reports, and were asked whether they were interested in learning under RBL, developing their own system of arguments for and against RBL. It is revealed that RBL will be successful in implementing online learning elements alongside traditional lessons (Chang, Shu-Nu, 2007). In the course of introducing RBL at Deakin University, when studying psychology, researchers stated that the systematic use of Internet resources and search tools on the Internet contributes to the learning outcomes of the practical orientation, increases the level of students' information culture, and forms their logical and critical. Conferencing services and webinars have been popular, allowing classes in virtual audiences, creating podcast libraries, holding conferences online, protecting student projects, and more (Holt, Rice, Armatas, 2002).

The similarity of the RBL process in these authors' studies is that in the educational process, information technologies and intensive independent search of information in various resources were actively used. Typically, one discipline was chosen to implement RBL. Among the students who chose the teaching profession, we did not record the fact of RBL implementation. Thus, theoretical analysis of the scientific literature, the provisions of modern approaches to the implementation of RBL showed that the pedagogical theory and practice focused on various aspects of RBL. At the same time, the problem of future teachers' RBL in Ukrainian pedagogy has not been systematically and reasonably interpreted. Therefore, our study 
differs from the previous ones in that we developed a system of future teachers RBL and determined the effectiveness of students' learning activities in this system. It has been found that RBL will be successful in combining traditional and innovative forms and learning methods, although an emphasis on innovation and information technology is desirable.

The analysis of scientific works made it possible to distinguish the characteristic features of the RBL:

- orientation (not only for the mastering of knowledge, skills, habits, but also for training the abilities of an active and independent study of the information environment);

- practicality (practical application of information resources in learning, life, future professional activities);

- potential infinity (use for processing an unlimited spectrum of information resources in solving a certain problem task);

- reality (student becomes self-directed in the process of learning that corresponds to real life and prompts for constant tracking of information, its adequate interpretation and further use);

- fundamentality (thanks to the experience of working with information resources to form a solid basis of knowledge, skills and habits that can be used in future educational and professional situations).

In the context of the training future teachers in higher education institutions, RBL is understood as one of the powerful means of forming a teacher of a new Ukrainian school - a personality, a professional, an innovator. "The Ukrainian school will be successful if it is joined by successful teachers. They - successful teachers and professionals - will resolve a multitude of issues regarding the quality of teaching, the volume of home assignments, communication with children and school administration. Children need a leader who can lead them forward, who likes their discipline, who teaches them professionally" - noted in the Concept of New Ukrainian School (the Concept of New Ukrainian School, 2016). It is clear that such teacher can become only a motivated, competitive, socially responsible professional, able to respond promptly and adapt to the changing conditions of the informational global world, open to the creative perception of new ideas and ready to implement them in practice. So, one of the main tasks of pedagogical universities education today is to prepare teachers who should become the real "agent of change" for the better for the school of the third millennium.

On the basis of the analysis of scientific literature the system of RBL future teachers is substantiated theoretically, containing the following subsystems: conceptual-target, structural-content, processtechnological, motivational, diagnostic and productive (Fig. 1).

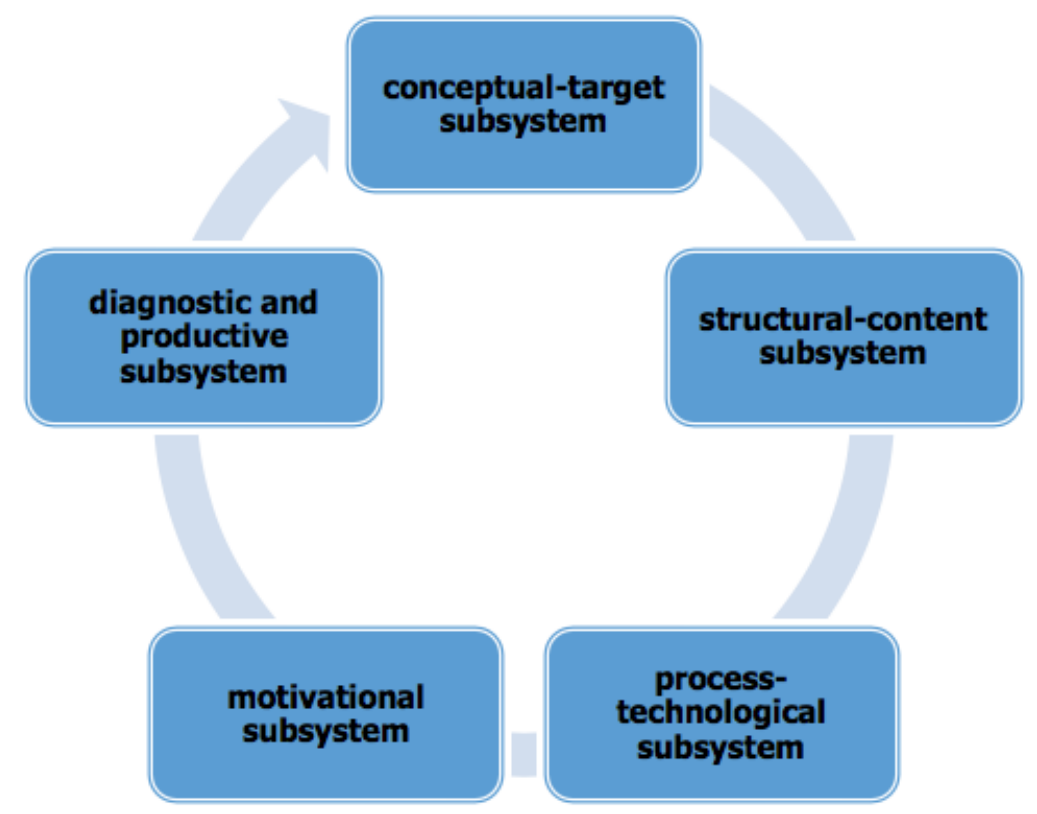

Figure 1. The RBL system of future teachers 


\section{Conceptual-target subsystem includes:}

purpose of the system (computer literacy, information competence, information culture of the teacher, its orientation towards education throughout their life);

social order for highly skilled teachers;

strategy of the development of the pedagogical university (the university's vision is the integral system of training of competitive personnel of the region by creative association of modern-level professionals; the mission of the university is the development of the system of education and science through the training of highly professional specialists, the establishment of the university as a leading pedagogical institution of higher education in the region);

the concept of RBL in higher education institutions, methodological approaches (resource, acmeological, student-centered, competence, systemic, cross-cultural, cloud-oriented, design), RBL principles (universality, autonomy and controllability, freedom of choice, self-regulation, continuity, individualization, internationalization, accessibility, rationalization, informational approach);

the essence of RBL is to provide the student (future teacher) the role of the explorer of the information environment, the teacher of higher educational establishment - the role of tutor, the librarian of higher educational establishment - the role of teacher-librarian, and ensuring freedom of choice of information resources for: effective acquisition of knowledge by students, acquisition of abilities and skills, outlined in the content of each discipline; improving the quality of teaching disciplines (a qualitative indicator and absolute success); Self-regulation of educational activity (formation of students' ability to see the ultimate goal of activity, independently find ways to achieve it and seek its implementation).

Structural-content subsystem reflects the content of the education of future teachers, aimed at developing their information competence and information culture as a well-defined system of theoretical knowledge and practical skills that students must and can master for a certain time, devoted to studying the discipline "Information Technologies in Education" - a fundamental component and an applied component that envisages enriching the contents of the curriculum of the future teacher training of the information and communication component, it includes the development and implementation of programs for the development of the digital competence of a modern teacher and the study of innovative teaching methods in higher education. Digital competence is a sure but, at the same time, critical application of information and communication technologies for creating, searching, processing, exchanging information at work, in public space and in private communication; information and media literacy, basics of programming, algorithmic thinking, database work, Internet security skills and cyber security; understanding of the ethics of working with information (copyright, intellectual property, etc.) (the Concept "New Ukrainian School", 2016).

Process-technological subsystem contains the technological support of the RBL process-pedagogical technologies (web-quest technology, educational project, Web 2.0, mindmapping, cloud technologies, Kaizen technology), forms of organization of training (lecture, video tutorial, practical classes, binary classes, webinar, open lessons); methods (case-method, virtual design, interactive discussions, partial search and research methods, Cinquain method, virtual "Metaplan", visual reading, etc.), training tools (printed and electronic manuals and textbooks, clouds, Internet resources, distance learning courses, virtual classes, etc.), which are most favorable for the successful formation of information competence and informational culture of future teachers in the educational environment of the University, and positions the study of the discipline "Information Systems and Technologies in education" as a didactic project.

Motivationalsubsystem is allocated with the purpose of developing the motivation to study modern information and communication technologies, providing positive motivation for training and future professional activity, the process of formation of informational competence and informational culture of future teachers during the study at the university as a whole, and reflects the didactic tool, which is expedient to use in educational the process of modern university to create success situations in educational activities (pedagogy of success). The motivation subsystem is represented by educational activities, master classes, trainings, workshops, webinars devoted to modern information technologies in education, etc.

The motivation RBL subsystem of future teachers is considered in a single system of formation of stable motives of students' professional activity in general. So, as the necessary conditions for the effective implementation of this process we consider: 
procedural-content: facilitation of educational activities; the introduction of personally oriented learning; individualization of educational and professional activity; observance of the correct correlation of theoretical knowledge and practical skills of educational activity; application of a competent approach; humanization and democratization of the educational process; the diversification of forms and methods of independent work of students; the corresponding style of work of the teacher and others;

didactic and educational: providing students with greater freedom to choose subjects to be studied, ways of doing business, information resources for learning; avoiding the stereotyping of conducting training sessions, using methods, forms and methods of teaching problem, interactive and research character; valuation of educational activity; distance learning and mobile learning; the structuring and differentiation of the educational material according to its importance; application of the principle of availability and use of other principles of didactics, etc.;

psychological: formation of stable interest in the profession; development of mental abilities of students, awareness of the nearest and final goals of education (close and long-term perspective), theoretical and practical significance of the acquired knowledge, professional orientation of educational activities, etc. (Ilchenko, 2017, 2018).

Diagnostic and productive subsystem provides monitoring of the effectiveness of educational activities of students (the methodology of the effectiveness of students' educational activities in the RBL system). The methodology was developed and adapted by the authors on the basis of I. Todorova's methodology (Todorova, 2011).

Methodology of Student Learning Effectiveness in the RBL System of Future Teachers

Students are invited to a questionnaire (Table 1). "Read the following sentences in the table. Read both the left and the right statement. Determine which one more accurately describes your opinion about RBL. Then circle only one digit (point), which shows the degree of certainty of this characteristic. The closer the figure to the statement, the more determined this characteristic (actualized on Webanketa https://rbl3.webnode. com.ua/on-line-anketuvannya/)".

Focus on the following scale:

1 -this characteristic prevails rather than is opposite;

2 - the characteristic is definitely defined;

3 - the characteristic is determined very strongly;

0 - hard to say.

Negative values - in contrast to positive ones. 
Table 1. Questionnaire for students

"+" Characteristics of studying

1. It is interesting to study, I am fascinated by the learning process

2. I study discipline on my own, voluntarily

3. I study diligently, persistently, systematically

4. I like to use different information resources of the Internet, work in virtual classes, use distance courses

5. I'm active at the classes, I'm curious

6. The purpose, volume and algorithm of carrying out the independent work are understandable to me

7. My marks of own work at the classes coincide with the teacher's estimates

8. I can look for information, analyze it

9. I can quickly and accurately process the found information

10. First of all, my thinking and imagination are working hard at the classes

11. I like to learn using social networks, web-sites, to create mindmap, perform web quests, work on network projects

12. I understand the concept of RBL

13. Educational information is used to perform practical exercises, analysis of specific situations, close to professional ones

14. The acquired training information is stored in memory for a long time

15 At classes the teacher uses the convenient methods and tools of $\mathrm{RBL}$, and I like it

16. At classes I do not get tired, I feel cheerful after lessons, I like e-learning

17 In order to study well, I do not need constant control from the teacher

18. At the classes I have a good mood, I feel confident

19. I feel support, respect and understanding from the teacher

20. RBL positively affects my professional training, stimulates the desire to study

Circle the necessary number "_"Characteristics of studying

$+3+2+10-1-2-3$

$+3+2+10-1-2-3$

$+3+2+10-1-2-3$

$+3+2+10-1-2-3$

$+3+2+10-1-2-3$

$+3+2+10-1-2-3$

$+3+2+10-1-2-3$

$+3+2+10-1-2-3$

$+3+2+10-1-2-3$

$+3+2+10-1-2-3$

$+3+2+10-1-2-3$

$+3+2+10-1-2-3$

$+3+2+10-1-2-3$

$+3+2+10-1-2-3$

$+3+2+10-1-2-3$

$+3+2+10-1-2-3$

$+3+2+10-1-2-3$

$+3+2+10-1-2-3$

$+3+2+10-1-2-3$

$+3+2+10-1-2-3$
1. I'm not interested in studying, I study without admiration

2. I study discipline under external pressure, by obligation

3. I study somehow, with laziness, not systematically

4. I do not like to use different information resources on the Internet, work in virtual classes, use distance courses

5. I'm passive at the classes, I'm not curious

6. The purpose, volume and algorithm of carrying out the independent work I don't understand

7. My marks of own work at the classes don't coincide with the teacher's estimates

8. I cannot look for information, analyze it

9. I cannot quickly and accurately process the found information

10. First of all, my memory is working hard at the classes

11. I don't like to learn using social networks, web-sites, to create mindmap, perform web quests, work on network projects

12. I don't understand the concept of RBL

13. Educational information is not used for practical exercises, analysis of specific situations close to professional ones

14. The acquired training information isn't stored in memory for a long time

15. At classes the teacher uses the convenient methods and tools of RBL, and I don't like

16. At classes I get tired, I feel exhausted after lessons, I don't like e-learning

17. In order to study well, I need constant control from the teacher

18. At the classes I have a bad mood, I feel uncertain

19. I feel disrespect, lack of support and understanding from the teacher

20. RBL negatively affects my professional training, doesn't stimulate the desire to study

Scale for assessing the effectiveness of students' educational activity in the RBL system

The value of the

coefficient

From +3 till $+1,9 \quad$ From $+1,8$ till

$+0,6$

From $+0,5$ till

From -0,6 till - 1,8

From $-1,9$ till -3

Efficiency level

Very high

High

Medium

Low

Very low 
Processing results. In the left column are listed statements that characterize the effectively organized student's educational activities, in the right - statements that characterize inefficiently organized learning activities. Points which close to the left column, have a "+" sign, close to the right "-.". All points in the left and right numbers are based on characters. Each subsystem of educational activity is submitted by five statements. In order to calculate the coefficient of overall effectiveness of educational activities, the total amount is divided by 20 (the number of statements in the form).

$E_{\text {over }}=\frac{\sum_{k=1}^{20} \text { point } s}{20}$, where $\mathrm{k}-$ the number of affirmation, $\mathrm{E}_{\text {over }}-$ coefficient of overall efficiency

The effectiveness of individual subsystems of educational activity is calculated by the sum of scores received by each of them.

$E_{m}=\frac{\sum_{K=1}^{5} \text { point } s}{5} E_{o}=\frac{\sum_{K=6}^{10} \text { point } s}{5} E_{i}=\frac{\sum_{K=11}^{15} \text { point } s}{5} E_{r}=\frac{\sum_{K=16}^{20} \text { point } s}{5}$

$E_{\text {over }}$ - coefficient of overall efficiency, questions №№ $1-20$;

$E_{\mathrm{m}}$ - coefficient of efficiency of the motivation subsystem, affirmations №№ $1-5$;

$E_{\mathrm{o}}$ - efficiency factor of the operating subsystem, affirmations №№ 6-10;

$E_{\mathrm{i}}$ - coefficient of efficiency of the information subsystem, affirmations №№11-15;

$E_{\mathrm{r}}$ - coefficient of efficiency of the regulatory subsystem, affirmations №№ 16-20.

\section{METHODOLOGY AND PROCEDURES}

Implementation of future teachers in the RBL of higher educational establishments in Poltava region (Poltava V. G. Korolenko National Pedagogical University, University of Ukoopspilks "Poltava University of Economics and Trade") was made within the pedagogical experiment.

Among the research methods used are: methods theoretical (analysis, comparison, generalization); methods pedagogical (pedagogical experiment, pedagogical observation); social and psychological methods (questioning), mathematical methods (mathematical calculation, ranking, regression). The basis of the empirical research was: Poltava V. G. Korolenko National Pedagogical University, University of Ukoopspilks "Poltava University of Economics and Trade"). The sample of the study was made by the undergraduates of the VI course of full-time and external forms of study of specialty "Secondary education", educational programs "Secondary education (natural sciences)", "Secondary education (computer science)", "Secondary education (mathematics)" - Poltava V. G. Korolenko National Pedagogical University; undergraduate students of the 6th year of the stationary and correspondence form of study in the specialty "Educational, Pedagogical Sciences", educational program "Pedagogics of Higher School" - University of Ukoopspilks "Poltava University of Economics and Trade".

The study covered the entire period of study in the magistracy - 1.4 years and was conducted in two stages: the first (2018) - at the beginning of the experiment, before the introduction of the RBL system; the second (2019) - at the end of the experiment, after the implementation of the RBL system. Quantitatively, a pedagogical experiment was involved 253 persons in control group (CG) and -240 persons in experimental group (EG).

As noted above, in the course of scientific research the methodology of I. Todorova (Todorova, 2011) was used, which was adapted by the authors. The methodology for revealing the effectiveness of students' educational activity in the system of RBL future teachers was offered to the respondents in the form of a questionnaire (see Table 1). Self-government bodies were involved in organizing a comfortable, frank, and objective survey. 
The survey was conducted anonymously on the basis of democracy and voluntary participation.

The results of the students' educational activity efficiency (before the introduction of the RBL system) are presented in Table 3 of the study, the results of diagnostics of the students' educational activity efficiency after the introduction of the RBL system of future teachers are shown in Table 4, the dynamics of changes in the levels of students' educational activity performance during the implementation of the RBL system are shown in Figure 7 The reliability of the results of experimental observations by the method of efficiency of students' educational activity in the RBL system services are due even regression analysis and build a trend line (see fig. 8).

Thus, the students of EG were invited to study a number of disciplines ("Pedagogy of Higher School", "Gender Approach to Pedagogy", "Teaching Methods in Higher Education Institutions", "History of Higher Education Pedagogy", "Organization of Scientific Research", "Innovative Technologies in Education", "Polycultural Education and Education in World Educational Systems", "Pedagogical Technologies of Education and Upbringing in Higher Education Institutions", "Autonomy of Higher Education Institutions", "Andragogy in the System of Pedagogical Sciences", "Management in education", "Innovative Paradigm of Education", "Sub-subject Relations between a Teacher and a Student in a Higher Education Institutions", "Persons in Historical and Pedagogical Discourse", "Information Systems in Innovation Activity") in a mixed form of learning (traditional + e-learning, integration of on-line courses from traditional classroom classes), among which the leading discipline "Information Technologies in Education" is defined.

To organize e-learning it has been developed open learning environment - OLE as an artificially formed environment, the structure and components of which contribute to the achievement of the goals of the educational process. The components of the learning environment are, first of all, the means of training (Zhuk, 2006).

OLE at RBL is a powerful tool for organizing distance education - a new organization of educational process in Ukrainian universities, based on the principle of independent student learning. Note that we are considering distance learning as a form of RBL (Kononets, 2013).

OLE - is accessible qualitative and quantitative set of information resources that are made possible for use in the educational process through distributed automated databases of data and knowledge, as well as computing resources offered and maintained in computer networks (corporate, continental, Internet), communication characteristics of these networks (Bykov, 2010).

The modern OLE of higher educational establishments that participated in the pedagogical experiment are potentially unlimited in terms of the amount of resources that can be used in the educational process, the number of users who can use its facilities and technologies, and therefore the number of students that can be jointly involved to solving a single didactic task.

In general, modern OLE for the implementation of the RBL system of future teachers consists of the following components:

- official sites of higher educational establishments;

- e-libraries;

- electronic educational resources (electronic manuals and textbooks, distance learning courses, virtual classes);

- file-servers of higher educational establishments (fig. 2). 


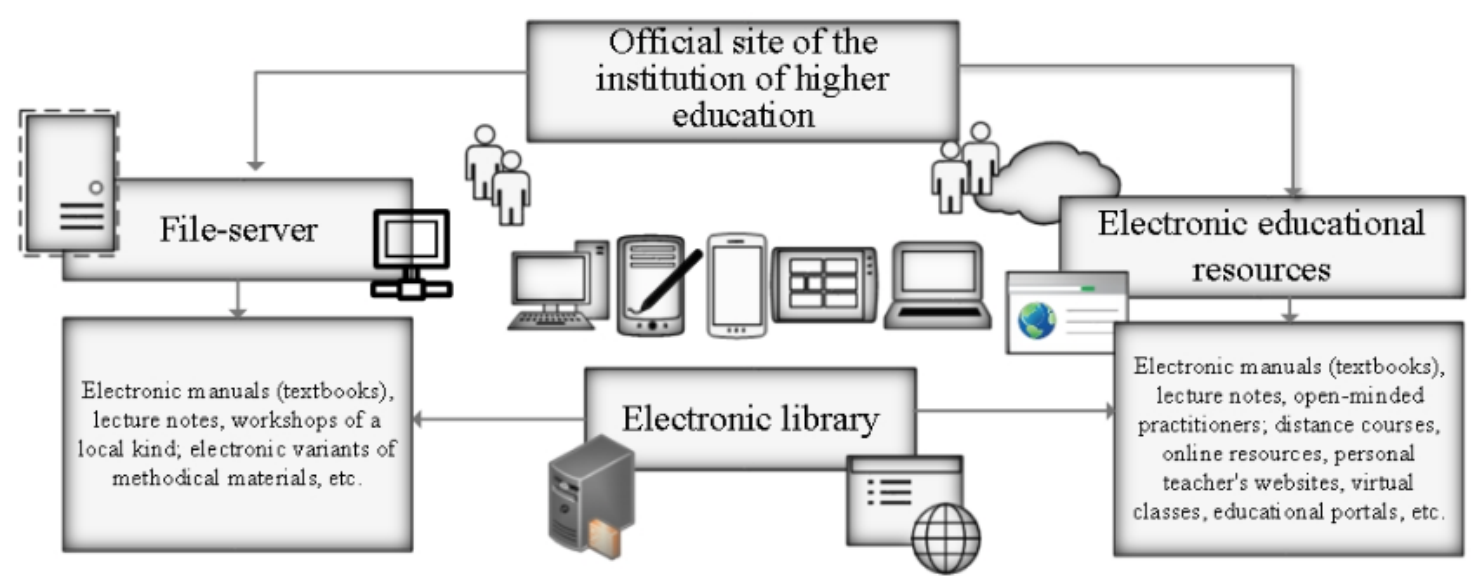

Figure 2. An open learning environment

The electronic educational resources used in the process of implementing the RBL system of future teachers are divided into 2 types: local and open.

1 type: local. The electronic educational resource (electronic tutorial, textbook, lecture notes, workshop) is necessarily a hypertext environment. Created with any program designed to develop electronic manuals (like compiled htmlfiles of Windows) or with the help of web-editor (for example, program FrontPage). It is localized on any media (disk, flash card, computer hard drive), or a separate file can be placed on the site or in any file storage. If you are hosting on the Internet, you must download the file to your computer. In general, such electronic educational resources need to be downloaded, opened and installed (depending on the type of data). In general, such electronic educational resources are placed on the file server of the educational institution.

2 type: open. An electronic educational resource is hosted on any web-site, effectively and fully functioning in any modern browser such as Internet Explorer, Google Chrome, Opera, MozillaFirefox, Yandex Browser etc. The possibility of on-line work is available without downloading from the Internet resource (open hypertext environment, all navigation maps are available, all hyperlinks are available for work, available for viewing all the content of the learning resource, it is possible to download individual files). To this type we include distance courses, personalized teacher sites, educational portals, virtual classes, etc.

An example of a distance course "Information Systems in Innovation" as a set of educational materials and educational services created in a virtual environment for organizing distance learning based on the service https://sites.google.com/ is shown on Figure 3.

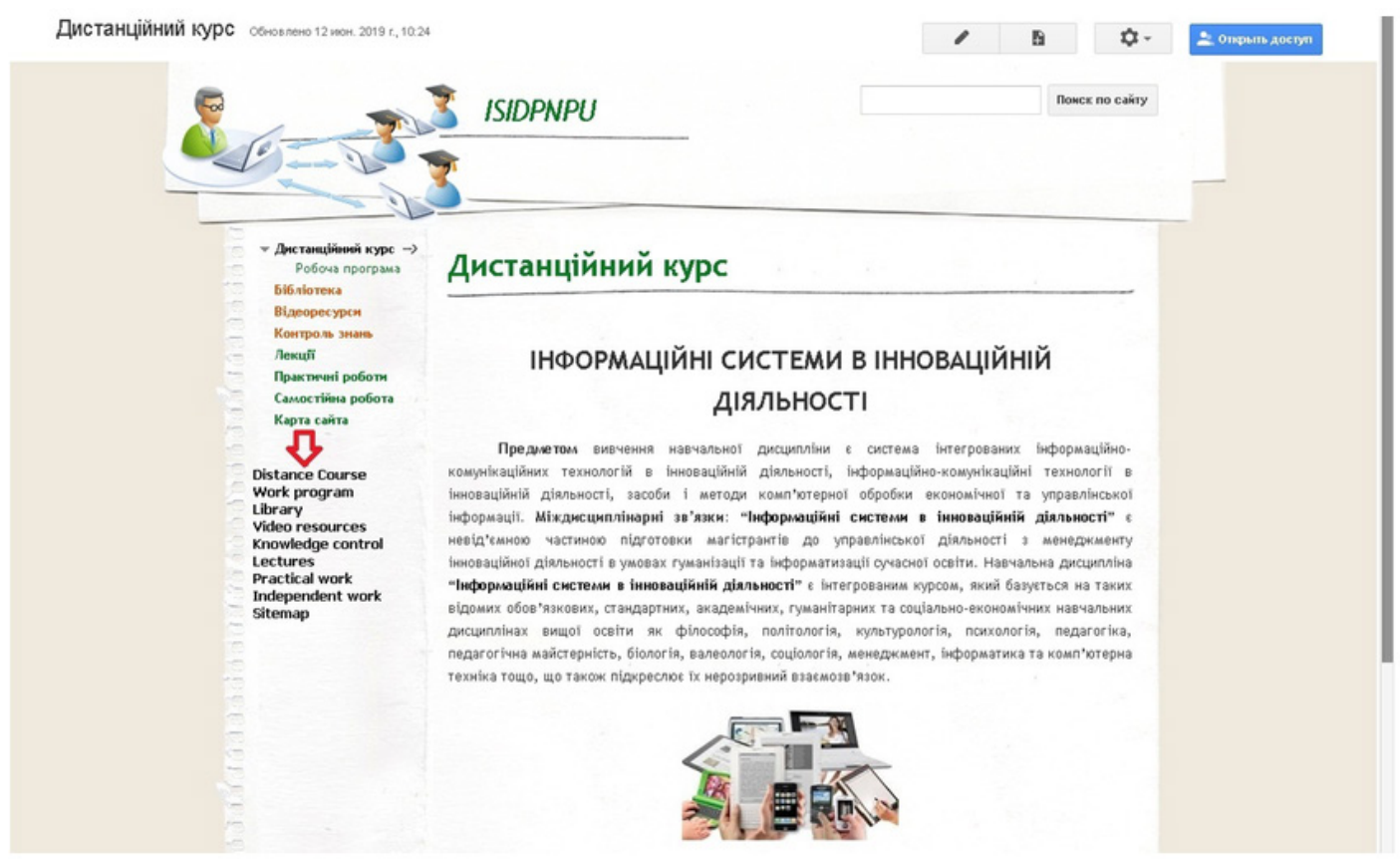

Figure 3. Distance course "Information Systems in Innovation" 
E-learning of students of the $\mathrm{EH}$ in the process of studying a number of disciplines was carried out in the virtual classes of the Google Classroom service, which made it possible: to create a single educational space for students of all groups of students from different higher educational establishments; combine traditional and distance learning through the creation of a hybrid education system while studying the discipline; consolidate various electronic educational resources on one platform; reorient the activities of teachers to develop new electronic learning tools and enhance their creative activity, the level of digital and methodological competence.

An example of virtual class "Persons in historical and pedagogical discourse" is shown on Figure 4.

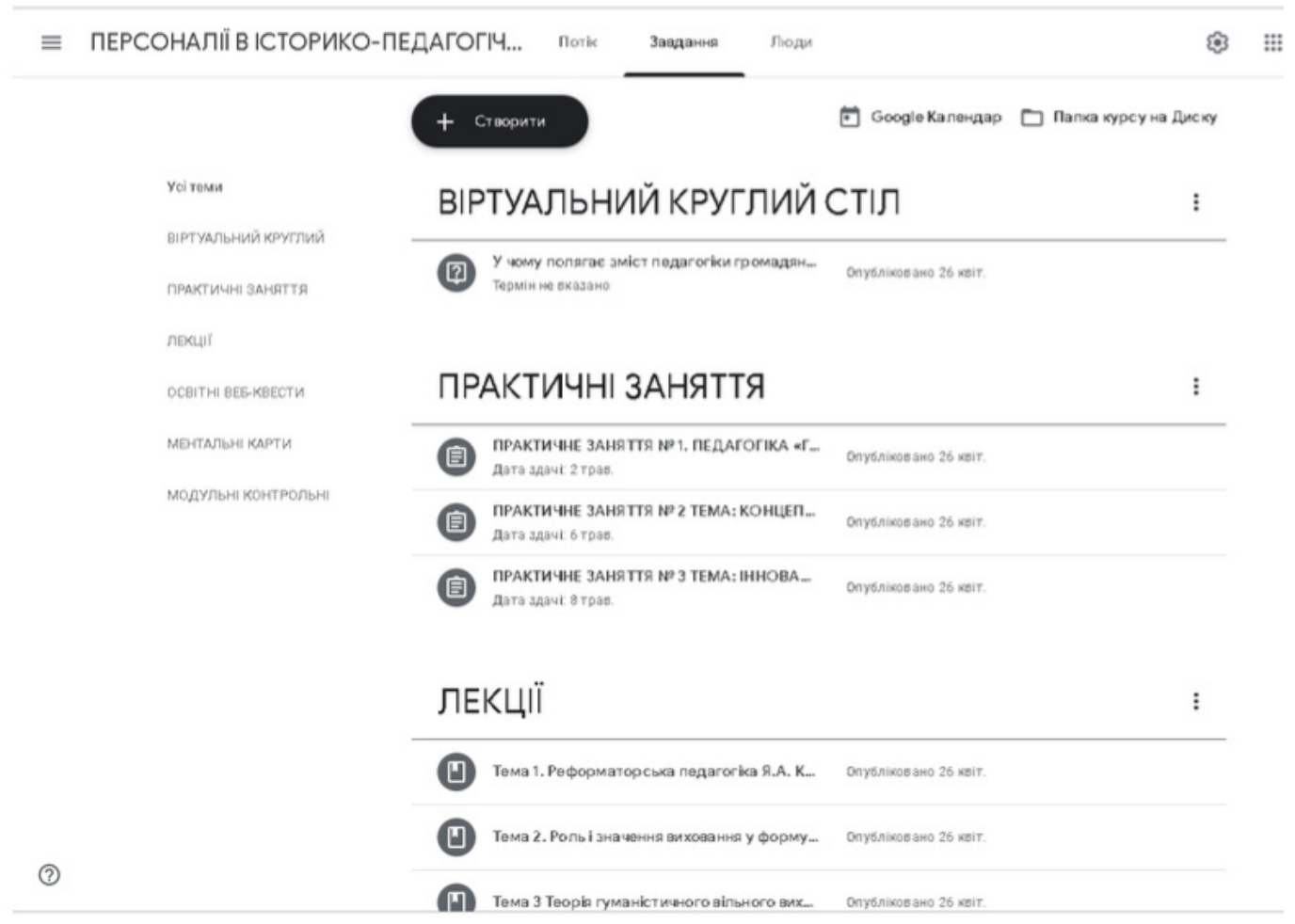

Figure 4. Virtual class "Persons in historical and pedagogical discourse" (tab "Tasks")

Let's emphasize the benefits of Google Classroom service while studying disciplines in the RBL system.

Convenience of setup. When creating a class, a code is automatically generated that students with a Google account use to join the class. This process eliminates the need to create pre-registries. Everything that is needed by the teacher is to communicate this code to the students in a convenient way or, with the student's email addresses (gmail.com), connect them independently (tab "People"), after which students receive an invitation letter to the e-mail address.

Automation. When a teacher creates a class in the Google Classroom environment, "Classroom" folder is automatically created on both its Google Drive with new attachments for each class, and on the disc of each student with separate folders for the classes they join. It allows you to organize information (documents, presentations, tables, etc.) in structured form and store it in one place, which has access from any device.

Simple interface. Work in the classroom is facilitated by a navigation system that is understandable for the instructor and the teacher. In the horizontal navigation bar, the resource contains three tabs: 'Flow', 'Tasks', 'People'. The first shows the activity of the course, the second - the tasks that are offered for execution, Google Calendar with the schedule and the course folder in Google Drive; the third contains a list of students and their email addresses, as well as information about teachers. This tab can be used to set up curricula, additional materials, etc.

The vertical navigation panel contains information on the list of topical tasks, as well as structured in separate blocks / topics educational materials, the transition to which is carried out in one click. Both the teacher and 
the students can see all the tasks on the main screen of the class in the 'Flow' tab. It allows you to control activities both in a particular class and at once in several classes. In just one click a teacher can add teaching resources to a class. This may be a question (open or with options); advertisement; task (containing both one and several components - documents, presentations, videos, links to Internet resources, etc., and, if necessary, use a re-present post).

Interactive control provides the ability to plan and set timing for tasks. Any of the activity elements (tasks, questions, announcements) can be published by the teacher immediately, can be saved as a draft or scheduled for further publication on a particular day and time. Thus, a teacher can plan a course in advance, and as the course progresses, students can access specific materials. Also, when creating each task, the teacher can determine the timing of its execution. It allows both the teacher and the students to monitor their own activities, determine the pace and schedule time for the tasks.

Feedback. Thanks to the combination advertisement, created by teacher in virtual classroom, and integrated ability to comment on tasks, the teacher and student always have the ability to communicate (both synchronous and asynchronous) and track the status of each task in real time. The service also allows the creation of surveys and thematic discussions. Therefore, students have an opportunity to answer the teacher's questions and share materials with other students. It's important to note that educational interaction can take place between the teacher and the individual student, and may have a group or collective character (for example, reviewing and commenting on an individual text job or working on a collaborative project in Google-presentation, etc.).

Personalization and individualization. All tasks, work, and marks (whether performed or not, checked or not) that were assigned within the class are displayed on the individual student page. Such page is generated and automatically updated by the service to automate the progress of the learning material. Despite the fact that Google Classroom does not have a rating journal as an element, the teacher has the ability to set up a numerical grade and form the details of the learning achievements. Graded materials can be exported and uploaded to the class environment or as a Google-Table. This allows students to keep an eye on their progress from the course, as well as illustrates the topics that need to be finalized. Significantly expands the ability to implement an individual approach to each student option, which allows the teacher to assign tasks for the entire stream, and distribute individual copies for each or a particular student in the classroom.

Thus, Google Classroom service during the study of discipline provides an opportunity to implement an individualized approach to learning, interactively monitor tasks, use individualized group methods in online environment, enhance motivation for learning, and serve as a means of implementing the concept of RBL in high school. (Kononets, 2018, 2019).

During the pedagogical experiment, the students' activity in the direction of using the resources of electronic libraries of institutions of higher education has been intensified:

University of Ukoopspilks "Poltava University of Economics and Trade" - e-library website http://lib.puet. edu.ua/ (fig. 5);

Poltava V. G. Korolenko National Pedagogical University - e-library website http://lib.pnpu.edu.ua/ (fig. 6). 


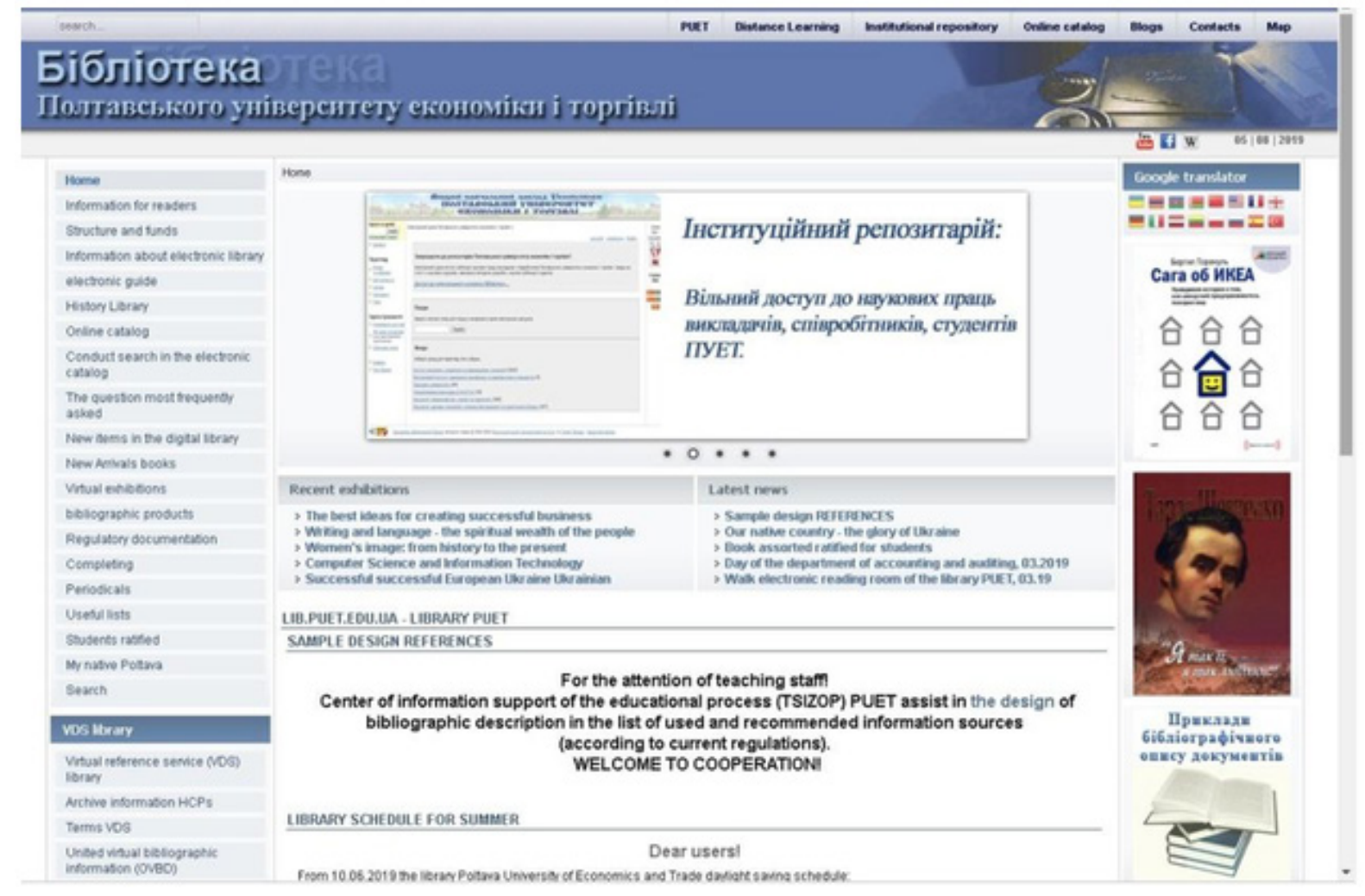

Figure 5. E-library of PUET

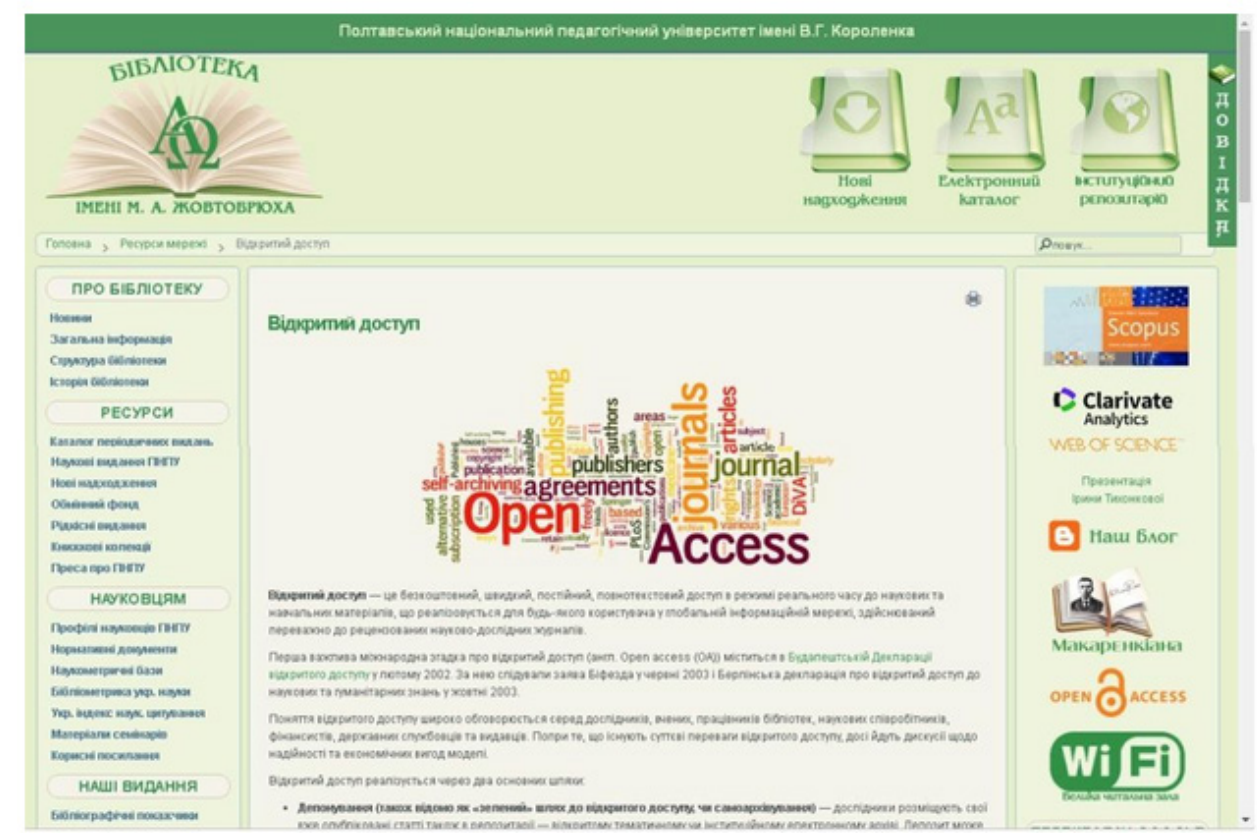

Figure 6. E-library of Pedagogical University

Our universities have become tradition of holding library classes, thematic information exhibitions, days of information, mini-seminars for students, where librarians help to get deeper into one or another topic, find relevant literature, work with catalogs, arrange a bibliography for course work, etc. The task of the librarian of the modern university is to interest the student in printed literature, to organize his independent work with the textbook and additional sources, to target independent search of information. In addition, 
the librarian, as well as the teacher, should become a student guide in the process of finding information among the Internet resources, since students and the library have access to the Internet, the university has a Wi-Fi zone and students have access to electronic resources of the library and the World Wide Web in any place. The modern librarian performs the basic social function of the library - to provide comprehensive information to the maximum extent.

Students of the Pedagogical University were able to attend the PUET electronic reading room, a virtual production laboratory, use an electronic kiosk, multimedia laboratories, and distance learning rooms. Thanks to the library resources of the PUET library, students have access to a large number of electronic guides and textbooks, digitized versions of printed literature that are not available at the pedagogical university. Instead, students at PUET were given access to a wide range of psychological and pedagogical literature of the electronic library of the Pedagogical University.

On the basis of PUET reading rooms with the involvement of specialists of the Inter-branch Institute for Advanced Training and Retraining of Specialists, which is a unit of PUET, the testing of structural and content subsystem of the RBL system of future teachers was carried out by introducing for the students of the EG course "Innovative Methods of Teaching in Higher School: the Newest in European and World practice" (author S. Nestulia).

Thus, today libraries of higher educational establishments of Poltava region create a powerful information system that provides students with not only effective search for educational information, but also the production of the information needed for each individual student, which is necessary for the effective management of all its resources, the creation of information and technical environment for optimal organization of RBL in general.

The experience of higher educational establishments in Poltava region in the process of training students of PUET and pedagogical university has shown the expediency of distinguishing organizational and pedagogical conditions for the implementation of the RBL system of future teachers as a set of interconnected circumstances, measures that ensure the purposeful management of the process of mixed learning, and the rules established in the system for providing high quality professional training.

These conditions must be considered systematically. Mixed RBL training for future teachers involves:

- understanding the RBL process as a multidimensional problem;

- definition of the essence, content, functions and parameters of the system;

- establishment of the features of the RBL functioning as a specific type.

Organizational-pedagogical conditions for the implementation of the RBL system of future teachers:

- Availability of Internet communication in higher educational establishments.

- Creation of an appropriate structure for providing communication in the system of training of future teachers.

- Presence of developed electronic educational resources of local and open type.

- Identifying and testing the ways and means of communication in the RBL system of future teachers.

- Make a timetable for all activities that simulate the process of RBL future teachers.

- Taking into account the tasks of educational programs, which are the training of future teachers.

- Introducing a mixed form of student training.

- Application of various forms and methods of organizing educational activities in the RBL system of future teachers.

- Implementation of tutor's function of teacher in the process of implementing the RBL system of future teachers (the individual support of the student is to provide him with the help in achieving the best educational result; tracking the process of training and providing feedback; conducting individual and group consultations (tutors); counseling and support individual educational process).

- Activation of the work of libraries and electronic libraries of higher educational establishments.

The conditions for the implementation of the RBL system for future teachers, listed above, are closely interrelated. As our research has shown, during the implementation of the RBL system of future teachers, it 
is necessary to take into account the whole range of conditions. Among the negative causes, we point out the stereotyped teaching and evaluation of educational activities in distance learning technologies.

The main task for the students of EG was the implementation of network projects on such topics as "Pedagogical technologies in Higher education institutions", "Pedagogical design in higher education institutions", "Personally oriented technologies of education and training", "Technology of Vitagene Education", "Debate Technology", "Training Technology", "Dialogue of Cultures", "Technology of Free School”, "Technology of Modular Education in Higher School", "Webinar as a Form of Information Technologies in Higher Education", "Coaching Technology in Higher Education", etc. (Table 2).

The organization of mixed learning envisaged the creation of conditions comfortable for students: 1) performance of tasks not only in the classrooms of the university and the library, but also in the cafe, in the park, in the student's dormitory, in the nature thanks to the virtual classes; 2) use of any information resources; 3) organization of feedback between the teacher and the student with the help of e-mail, Viber application.

Table 2. An example of a network project

\begin{tabular}{|c|c|}
\hline \multicolumn{2}{|l|}{ Author(s) of a project: } \\
\hline \multirow{4}{*}{ Student's name and surname: } & 1. \\
\hline & 2. \\
\hline & 3. \\
\hline & 4. \\
\hline \multicolumn{2}{|l|}{ Group: } \\
\hline \multicolumn{2}{|l|}{ Project Manager: } \\
\hline \multicolumn{2}{|c|}{ Name of the educational institution: } \\
\hline \multicolumn{2}{|c|}{ Discipline: PEDAGOGICAL TECHNOLOGIES OF EDUCATION AND TRAINING IN HIGHER SCHOOL } \\
\hline \multicolumn{2}{|c|}{ Description of the project: } \\
\hline Theme of the project: & $\begin{array}{l}\text { MODERN PEDAGOGICAL TECHNOLOGIES AND PEDAGOGICAL DESIGNING IN } \\
\text { HIGH SCHOOL }\end{array}$ \\
\hline
\end{tabular}

Tasks of the project:

1. Find out what the peculiarities of traditional learning technologies are.

2. Outline the classification parameters of traditional education.

3. Show the features of the methodology of traditional learning technology.

4. Develop ways to improve teaching methods as a means of intensifying the educational process.

5. Develop their own instructional guidelines for implementing group learning forms.

6. Describe the classification of gaming learning technologies by H. Selevko. Suggest your own variant.

7. Develop the technological scheme of the business training game.

8. Prepare a platform for online group discussion on "Pedagogical technologies of higher education on the basis of humanization and democratization of pedagogical relations".

9. Make a glossary to the topic.

10. Find a bibliography, useful links to Internet resources to this topic.

11. Propose recommendations on the structure of the educational project of the educational establishment.

12. Develop draft copyright, modification or adaptive programs.

13. Reveal the theoretical foundations of developmental training technology.

14. Design the pedagogical situation of your choice as an object of pedagogical design. 


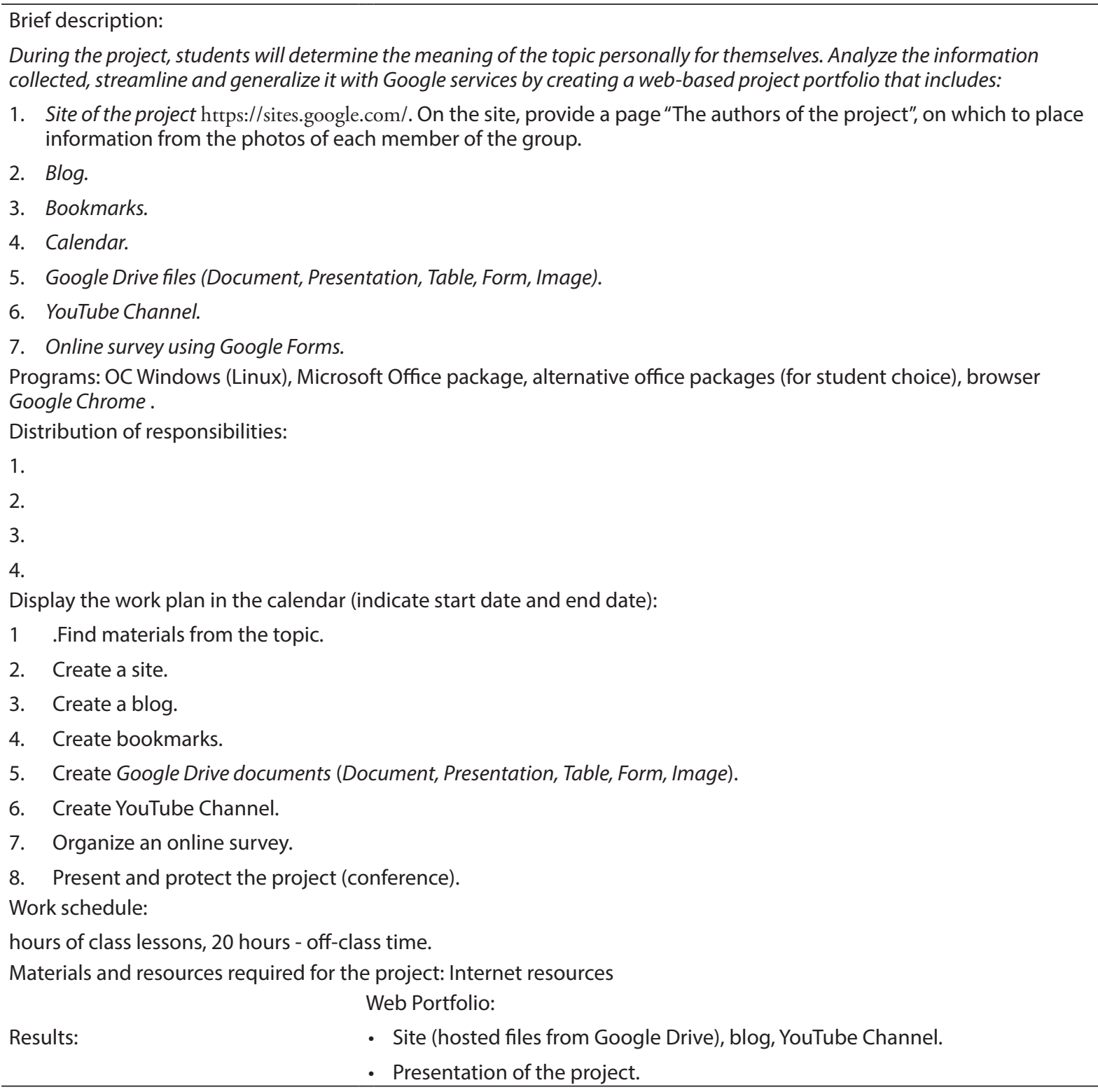

CG students did not implement network projects. They worked on conventional projects under traditional training conditions.

It should be noted that the project activity of students was carried out in small groups, there were 3-4 students involved to one project. The experience of using project methods proves its high efficiency in raising the level of professional socialization of future specialists, digital competence, as well as the level of their information culture. Joint collective work on a network project allows students to develop the following skills and abilities: to use computer technology (laptops, smartphones, etc.) for educational purposes; to cooperate, to bear responsibility; to enter a group or team and to contribute; to prove solidarity; be able to organize their work in interaction with other people; be able to collaborate and work in a group; to make decisions - to settle disagreements and conflicts; be able to negotiate; be able to design and perform various types of work.

It should be noted that the implementation of the network project was carried out within 2 months.

\section{RESULTS AND DISCUSSIONS}

Before the introduction of the RBL system of future teachers, the effectiveness of students' educational activity was determined by I. Todorova's methodology. (Todorova, 2011). The results are shown in Table 3: 
Table 3. Effectiveness of students' educational activities (before the introduction of the RBL system)

\begin{tabular}{cccccc}
\hline Efficiency level, \% & Very high & High & Average & Low & Very low \\
\hline CG(253) & 0 & 17,79 & 49,41 & 27,67 & 5,13 \\
EG(240) & 0 & 15,83 & 49,58 & 27,09 & 7,5 \\
\hline
\end{tabular}

As can be seen from Table 3, the level of student performance varies from very low (CG - 5,13\%, EG - 7,5\%) to high (CG - 17,79\%, EG - 15,83\%). This is understandable, because all the same certain knowledge and ability to work independently, use of electronic educational resources, Internet resources for students is due to the IT orientation of the discipline and the knowledge acquired in computer science.

The results of diagnosing the effectiveness of student learning activities after the introduction of the RBL system of future teachers are shown in Table 4.

Table 4. Effectiveness of students' educational activities (before and after the introduction of the RBL system)

\begin{tabular}{ccccccccccc}
\hline Efficiency level, \% & \multicolumn{2}{c}{ Very high } & \multicolumn{2}{c}{ High } & \multicolumn{2}{c}{ Average } & \multicolumn{2}{c}{ Low } & \multicolumn{2}{c}{ Very low } \\
\hline & Before & After & Before & After & Before & After & Before & After & Before & After \\
\hline CG(253) & 0 & 0 & 17,79 & 20,16 & 49,41 & 49,01 & 27,67 & 26,88 & 5,13 & 3,95 \\
EG(240) & 0 & 6,25 & 15,83 & 20,42 & 49,58 & 58,75 & 27,09 & 14,58 & 7,5 & 0 \\
\hline
\end{tabular}

From Table 4, we can see that the levels of student performance in the implementation of the RBL system were distributed as follows.

Very high: in EG - 6,25\%, in CG - 0\% (at the beginning stage in CG and EG - 0\%).

High: in EG - 20,42\%, in CG - 20,16\% (at the beginning stage in EG - 15,83\%, in CG - 17,79\%).

Average: in EG - 58,75\%, in CG - 49,01\% (at the beginning stage in EG - 49,58\%, in CG - 49,41\%).

Low: in EG - 14,58\%, in CG - 26,88\% (at the beginning stage in EG-27,09\%, in CG - 27,67\%).

Very low: in $E G-0 \%$, in CG - 3,95\% (at the beginning stage in EG - 7,5\%, in CG - 5,13\%).

The dynamics of changes in the levels of students' academic performance at the introduction of the RBL system is visualized on Figure 7.

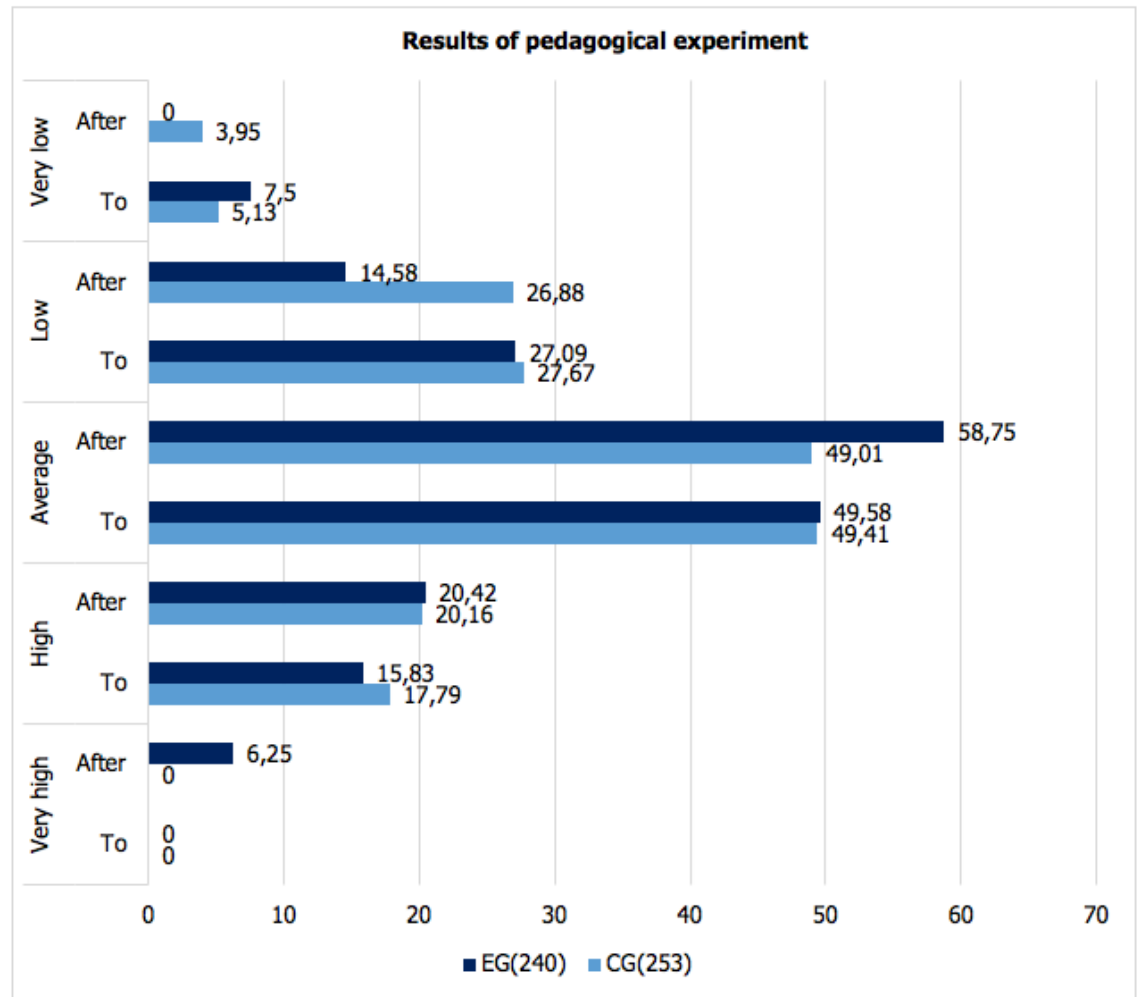

Figure 7. The dynamics of change 
The reliability of the results of experimental observations on the methodology of the effectiveness of students' educational activity in the RBL system was determined using regression analysis and trend line construction. (Figure 8).

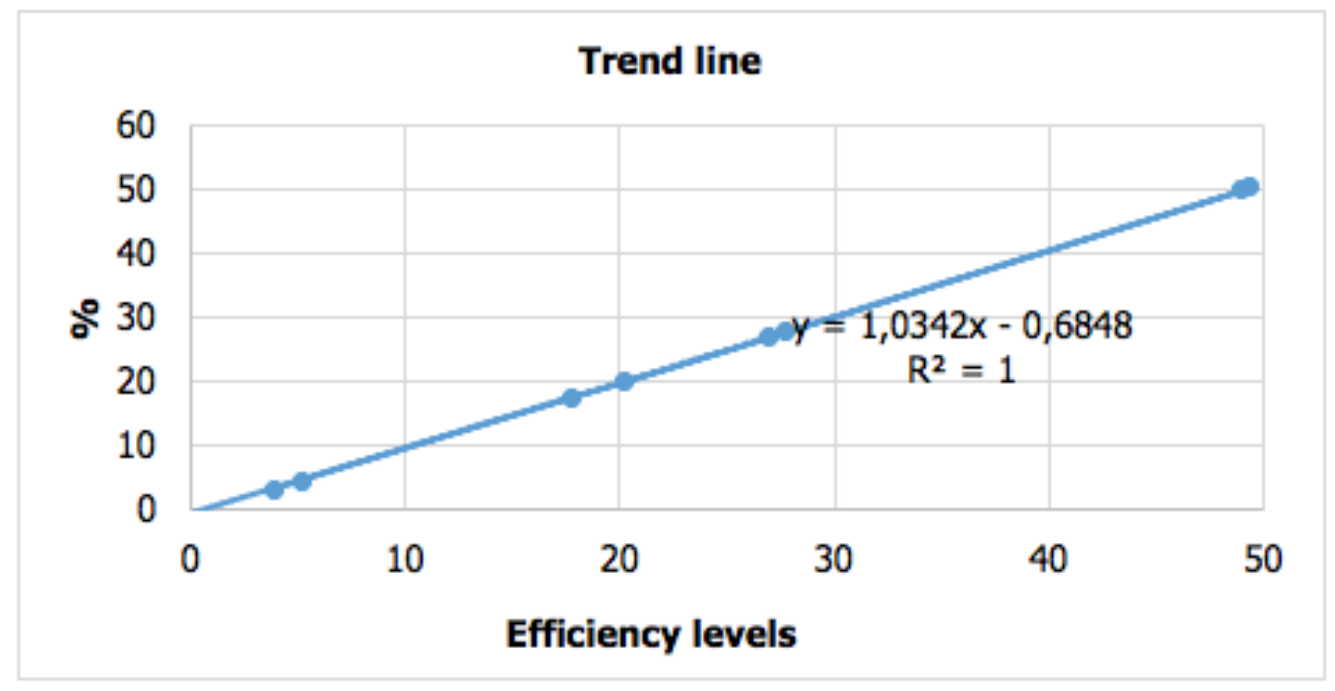

Figure 8. Analysis using the trend line

In Figure 8 "Efficiency levels" axis correspond to the following scale: 1-10 - very low level, 10-20 - low, 20-30 - average, 30-40 - high, 40-50 - very high. The constructed trend line shows that the indicators of the obtained values are stable and uniformly increasing from very low to very high. The probability of approximation is $\mathrm{R}^{2}=1$, which means the reliability of the constructed trend line.

The positive results of the experimental work were discussed and analyzed by the teachers of General Pedagogy and Andragogy Department (Poltava V. G. Korolenko National Pedagogical University) and Department of Economic Cybernetics, Business Economics and Information Systems (University of Ukoopspilks "Poltava University of Economics and Trade") at a joint meeting of the scientific round table "Implementation of a system of resource-based learning of future teachers". It was noted the positive dynamics of changes in the levels of students' educational activity in the implementation of the RBL system, was discussed further vector of development of topics of network projects, didactic tools of motivational and proceduraltechnological subsystems; was proposed extension of the list of topics of network projects with emphasis on practically oriented component of training of future educators. It was also decided to develop joint distance courses, virtual classes, electronic manuals for replenishing the e-libraries of universities, as well as to create a Ukrainian OLE for teaching future teachers and wide popularization among the educational community of the RBL system and its implementation in higher education institutions, not only in higher education, but also throughout Ukraine and beyond.

\section{CONCLUSION}

The effectiveness of the RBL system of future teachers, which consists of 5 subsystems (conceptualtarget, structural-content, process-technological, motivational, diagnostic and productive) is theoretically substantiated and experimentally verified. The RBL system was implemented in the higher educational establishments of Poltava region.

The organizational and pedagogical conditions of the implementation of the RBL system of future teachers as a set of interconnected circumstances, measures ensuring the purposeful management of the process of mixed learning, and the rules established in the system for ensuring high quality of professional training in higher educational establishments are identified.

The effectiveness of the RBL system for future teachers (the level of effectiveness of students' educational activity in the RBL system) indicates positive statistically significant changes. Very high level: in EG - 
$6,25 \%$, in CG - 0\% (at the beginning stage in CG and EG - 0\%). High: in EG - 20,42\%, in CG - 20,16\% (at the beginning stage in EG - 15,83\%, in CG - 17,79\%). Average: in EG - 58,75\%, in CG - 49,01\% (at the beginning stage in EG - 49,58\%, in CG - 49,41\%). Low: in EG - 14,58\%, in CG - 26,88\% (at the beginning stage in EG - 27,09\%, in CG - 27,67\%). Very low: in EG - 0\%, in CG - 3,95\% (at the beginning stage in EG - 7,5\%, in CG - 5,13\%). The statistical verification of the results of the experiment according to this technique showed that the indicators of the obtained values are stable and evenly increased from very low to very high. The obtained probability of approximation confirmed the reliability of the obtained forecast.

The research does not exhaust all aspects of the identified problem. The obtained theoretical and practical results form the basis for further study of the problem in the aspect of identifying the specific ways of organizing effective cooperation with libraries in Ukraine and other countries, with foreign educational institutions that train future teachers, studying the directions of introduction of RBL, building up an open partnership with higher education institutions and the creation of a new generation of universities using innovative technologies.

\section{RECOMMENDATIONS}

Implementation of the RBL system for future teachers in the higher education institutions of Poltava region made it possible to formulate the following recommendations:

to establish cooperation with other higher education institutions and network cooperation for creating a common open educational environment;

to build the educational process of future teachers preparing on the base of mixed form of learning (traditional learning and e-learning);

to prepare and implement the scientific and methodological provision of the process of RBL of future teachers (textbooks, manuals, electronic educational resources, distance learning courses, etc.) in the educational practice of higher education institutions;

to intensify the activity of libraries and electronic libraries of in the educational practice of higher education institutions, to transform the role of a librarian to a teacher-librarian students and teachers to be encouraged to work in virtual classes, to use a wide range of information resources, to build an individual educational trajectory of training;

it is expedient for teachers to develop personal websites which will be their visiting card and will reflect the scientific and pedagogical activity;

to improve forms, methods and learning tools, taking into account the concept of RBL in higher education and the paradigm "lifelong learning".

\section{BIODATA and CONTACT ADDRESSES of AUTHORS}

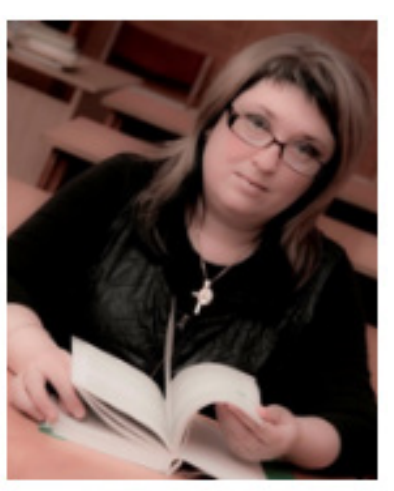

Dr. Natalia KONONETS, Doctor of Pedagogical Sciences, Associate Professor of the Department of Enterprise Economics and Economic Cybernetics of the University of Ukoopspilks "Poltava University of Economics and Trade". Labour has opposed the Ministry of Agrarian Policy and Food of Ukraine "Badge of Honour". Studs the problem of developing electronic teaching aids, the methodology of teaching the disciplines of the computer cycle, didactic fundamentals of resource-based learning of disciplines of the computer cycle. Lecturer in workshops on the development of electronic educational resources. Works on developing a concept of resource-based learning in higher education. $\mathrm{He}$ is the author of over 160 scientific works on pedagogical sciences: didactics, vocational education, information technologies in education. 


\section{Natalia KONONETS}

University of Ukoopspilks "Poltava University of Economics and Trade", Department of Enterprise Economics and Economic Cybernetics

Address: 36034, Poltava, st. Primakov, 12-a, kv.47, Ukraine

Phone: +38-066-12-12-741

Email: natalkapoltava7476@gmail.com

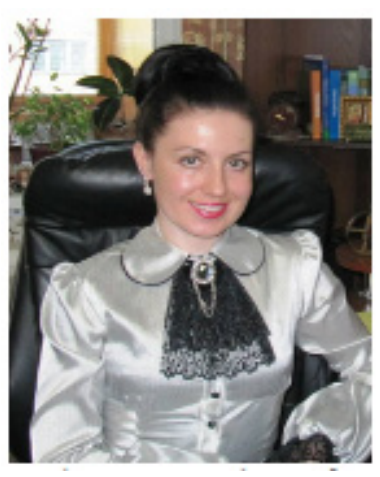

Dr. Olena ILCHENKO, Doctor of Pedagogical Sciences, Head of the Department of General Pedagogy and Andragogy, Poltava V. G. Korolenko National Pedagogical University. Present research interests include development of persistent motivation for students' professional work, in particular future teachers' motivation as pertaining to the ROL subsystem. O. Ilchenko has organized a number of scientific conferences dedicated to teacher training, distance learning, and creating digital educational resources (incl. the National Scientific and Practical Conference "Teacher Training in Ukraine: Research, Strategy, and Prospects" (Poltava, 2018), the National Scientific and Practical Conference "Higher School Pedagogy: Strategy, Prospects, and Advanced Studies" (Poltava, 2017) and others). She is Head of the Department which allows students to graduate from a Master's degree programme (second cycle) as well as a $\mathrm{PhD}$ programme in "011 Education sciences". Students have the opportunity to pursue certain courses through distance learning.

\section{Olena ILCHENKO}

Poltava V. G. Korolenko National Pedagogical University, Department of General Pedagogy and Andragogy Address: 36020, Poltava, st. Opitna, 3, kv.27, Ukraine

Phone: +38-098-39-37-414

Email: ilchenko.olena@gmail.com

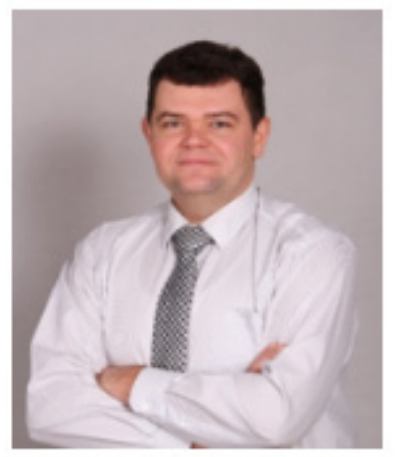

Dr. Volodymyr MOKLIAK, Doctor of Pedagogical Sciences, Associate Professor of the Department of General Pedagogy and Andragogy, Poltava V. G. Korolenko National Pedagogical University. Studies the history of development of domestic and foreign educational systems, the development of autonomy in the universities of Ukraine in the XIX and early XX centuries, information technologies in education, use of Google services in the educational process. Teaches pedagogical teaching technologies, pedagogy, pedagogy of higher education. Develops out the distance courses for students using different platforms. Author of more than 120 publications on pedagogy, history of pedagogy, computer science, mathematics.

Volodymyr MOKLIAK

Poltava V. G. Korolenko National Pedagogical University, Department of General Pedagogy and Andragogy Address: 36021, Poltava, st. Stepovogo Frontu, 7, fl. 36, Ukraine,

Phone: +38-050-304-32-85

E-mail: vovchik01071981@gmail.com 


\section{REFERENCES}

Биков, В.Ю. (2010). Відкрите навчальне середовище та сучасні мережні інструменти систем відкритої освіти. Науковий часопис НПУ імені М. П. Драгоманова. Серія 2 : Комп〉ютерно-орієнтовані системи навчання. № 9. С. 9-15. [Bykov, V.Y. (2010). An open educational environment and modern network tools for open education systems. Scientific journal of National Pedagogical Dragomanov University. Series 2 : Computer-based learning systems. № 9. Pp. 9-15.]

Жук, Ю.О. (2006). Проблеми фрормування навчального середовища сучасної школи. Моделі розвитку сучасної української школи: Матеріали Всеукраїнської науково-практичної конференції (Черкаси - Сахнівка, жовтень 2006 р.). Київ : СПД Богданова А.М. С. 71-77. [Zhuk, Y.O. (2006). Problems of forming the educational environment of a modern school. Models of development of modern Ukrainian school: Materials of the All-Ukrainian scientific and practical conference (Cherkasy - Cakhnivka, October 2006). Kyiv : SPD Bohdanova A. M. Pp. 71-77.]

Ільченко, О.Ю. (2017). Формування мотивів навчально-пізнавальної діяльності майбутніх учителів як психолого-педагогічна проблема. Педагогічні науки: зб. наук. праць. Полтава : ПНПУ імені В. Г. Короленка. Вип. 69. С. 57-62. [Ilchenko, О.Y. (2017). Formation of motives of educational and cognitive activity of future teachers as a psychological and pedagogical problem. Pedagogical sciences: a collection of scientific works. Poltava : PNPU. Volume 69. Pp. 57-62.]

Ільченко, О.Ю. (2018). Умови фрормування мотивів навчально-пізнавальної діяльності студентів. Збірник наукових праць викладачів, аспірантів, магістрантів і студентів фрізико-математичного фракультету. Полтава : ТОВ «АCMI». С. 210-213. [Ilchenko, O.Y. (2018). Conditions for forming the motives of students' educational and cognitive activity. Collection of scientific works of teachers, post-graduate students, graduate students and students of the Faculty of Physics and Mathematics. Poltava : Ltd. "ASMI". Pp. 210-213.]

Кононец, Н.В. (2019). Система управління навчанням Google Classroom у профресійній підготовці фрахівців. Методика викладання природничих дисциплін у середній та вищій школі (XXVI Каришинські читання): матеріали міжнар. наук.-практ. конфр. (Полтава, травень 2019 р.). Полтава : ТОВ «Сімон». С. 171-173. [Kononets, N.V. (2019). Google Classroom Learning Management System in Professional Training. Methodology of teaching natural sciences in the secondary and high school (XXVI ${ }^{\text {th }}$ Karyshynski readings): Materials of the international scientific and practical conference (Poltava, May 2019). Poltava : Ltd. "Simon". Pp. 171-173.]

Кононец, Н.В. (2013). Дистанційне навчання як форма ресурсно-орієнтованого навчання студентів заочного відділення. Гуманітарний вісник ДВНЗ «ПереяславХмельницький державний педагогічний ун-т імені Григорія Сковороди». Київ : Гнозис. Додаток 1 до Вип. 29. Том II : Тематичний випуск «Міжнародні Челпанівські психолого-педагогічні читання». С. 365-372. [Kononets, N.V. (2013). Distance learning as a form of resource-based learning for correspondence students. Humanitarian Visnyk of PereiaslavKhmelnytskyi H. S. Skovoroda State Pedagogical University. Kyiv : Hnozys. Apendix 1 to Issue 29. Volume II : Thematic issue "International Chelpansvski Psychological and Pedagogical Readings". Pp. 365-372.]

Кононец, Н. В. (2016). Дидактичні основи ресурсно-орієнтованого навчання дисциплін комп'ютерного циклу студентів аграрних коледжів. Дисертація доктора педагогічних наук. Полтава. 473 с. [Kononets, N.V. (2016). Didactic bases of resourcebased learning computer sciences cycle students of agrarian colleges. Thesis for a Doctor's Degree in Pedagogical Sciences. Poltava. 473 p.].

Кононец, Н.В. (2018). Концепція ресурсно-орієнтованого навчання у вищій школі. Витоки педагогічної майстерності: зб. наук. праць. Полтава : ПНПУ імені В. Г. Короленка. Вип. 22. С. 103-107. [Kononets, N.V. (2018). The concept of resource-based learning in high school. Origins of pedagogical skill: a collection of scientific works. Poltava : PNPU. Issue. 22. Pp. 103-107.] 
Концепція «Нової української школи». (2016). URL: https://base.kristti.com.ua/wp-content/ uploads/2017/10/rozd_1_Oglyad.pdf (дата звернення: 02.08.2019). [Concept of "New Ukrainian School" [E- resource] // Ministry of Education and Science of Ukraine. - 2016. Resource Access Mode: https://base.kristti.com.ua/wp-content/uploads/2017/10/rozd_1_Oglyad. pdf]

Тодорова, І.С., Павленко В.І. (2011). Психологія і педагогіка. Київ : Центр учб. л-ри. 228 c. [Todorova, I.S., Pavlenko, V.I. (2011). Psychology and pedagogy. Kyiv : Centre of studying literature. p. 228]

Barbara A. Greene and Susan M. Land. (2000). A Qualitative Analysis of Scaffolding Use in a Resourcebased Learning Environment Involving the World Wide Web, 23 J. Educational Computing Research 151-152.

Chang, Shu-Nu. (2007). Teaching argumentation through the visual models in a resource-based learning environment / Asia-Pacific Forum on Science Learning and Teaching, Volume 8, Issue 1, Article 5 (June, 2007).

Greenhow, Christine; Dexter, Sara; Riedel, Eric. (2006). Methods for Evaluating Online, Resource-Based Learning Environments for Teachers. Journal of Computing in Teacher Education. 23. (1, Fall), 21-28.

Hadjerrouit, S. (2010). A conceptual framework for using and evaluating Web-based learning resources in school education. Journal of Information Technology Education, 9, 53-79.

Hannafin, M. J., Hill, J. R. (2008). Resource-based learning. In M. Spector, D. Merrill, J. Van Merrienboer, M. Driscoll (Eds.). Handbook of Research in Educational Technology (3 ${ }^{\text {rd }}$ ed.). NewYork : Lawrence Erlbaum. 525-536.

Holt, Dale; Rice, Mary and Armatas, Christine 2002, Issues arising from an online resource-based learning approach in first year psychology, in Winds of change in the sea of learning: proceedings of the 19 th annual conference of the Australian Society for Computers in Learning in Tertiary Education (ASCILITE), UNITEC Institute of Technology, Auckland, New Zealand. - Pp. 287-297.

Laverty, C. (2001). Resource-Based Learning. Ontario : Queen's University, Kingston.

Leo Tan Wee Hin (National Institute of Education, Singapore) and R. Subramaniam (National Institute of Education, Singapore). (2005). E-Learning and Virtual Science Centers. 457

Margaret (Meg) Butler. Resource Based Learning and Course Design (2011). Law Library Journal, 2012; Georgia State University College of Law, Legal Studies Research Paper No. 2011-24.

Niemi, H. (2008). Research-based teacher education for teachers' lifelong learning. Lifelong learning in Europe. 13 (2008) 1, 61-69.

Ryan, Malcolm, Wells, Julian, Freeman, Alan and Hallam, George (1996) Resource-based learning strategies: implications for students and institutions. ALT-J, 4(1), 93-98.

Sikstrom, Inger Edebro; Westerlund, Mari-Ann. (2011). Umea, Sweden-Saskatoon, Canada: Resource-Based Learning Study Tour. A Report of a Study Tour of Saskato on School Libraries. 2001-10-21. p. 98 